University of Nebraska - Lincoln

DigitalCommons@University of Nebraska - Lincoln

USDA National Wildlife Research Center - Staff Publications
U.S. Department of Agriculture: Animal and Plant Health Inspection Service

2011

\title{
Modeling Connectivity of Black Bears in a Desert Sky Island Archipelago
}

\author{
Todd C. Atwood \\ USDA National Wildlife Research Center, Fort Collins, CO, todd.c.atwood@aphis.usda.gov \\ Julie K. Young \\ USDA/APHIS/WS National Wildlife Research Center, julie.k.young@aphis.usda.gov \\ Jon P. Beckmann \\ Wildlife Conservation Society, North America Program, Bozeman, MT \\ Stewart W. Breck \\ USDA/APHIS/WS National Wildlife Research Center, stewart.w.breck@aphis.usda.gov \\ Jennifer A. Fike \\ Purdue University \\ See next page for additional authors
}

Follow this and additional works at: https://digitalcommons.unl.edu/icwdm_usdanwrc

Part of the Environmental Sciences Commons, and the Life Sciences Commons

Atwood, Todd C.; Young, Julie K.; Beckmann, Jon P.; Breck, Stewart W.; Fike, Jennifer A.; Rhodes, Olin E. Jr.; and Bristow, Kirby D., "Modeling Connectivity of Black Bears in a Desert Sky Island Archipelago" (2011). USDA National Wildlife Research Center - Staff Publications. 1013.

https://digitalcommons.unl.edu/icwdm_usdanwrc/1013

This Article is brought to you for free and open access by the U.S. Department of Agriculture: Animal and Plant Health Inspection Service at DigitalCommons@University of Nebraska - Lincoln. It has been accepted for inclusion in USDA National Wildlife Research Center - Staff Publications by an authorized administrator of DigitalCommons@University of Nebraska - Lincoln. 


\section{Authors}

Todd C. Atwood, Julie K. Young, Jon P. Beckmann, Stewart W. Breck, Jennifer A. Fike, Olin E. Rhodes Jr., and Kirby D. Bristow 


\title{
Modeling connectivity of black bears in a desert sky island archipelago
}

\author{
Todd C. Atwood ${ }^{\mathrm{a}, \mathrm{b}, *}$, Julie K. Young ${ }^{\mathrm{c}, \mathrm{d}}$, Jon P. Beckmann ${ }^{\mathrm{e}}$, Stewart W. Breck ${ }^{\mathrm{b}}$, Jennifer Fike ${ }^{\mathrm{f}}$, \\ Olin E. Rhodes Jr. ${ }^{\text {, Kirby D. Bristow }}{ }^{\mathrm{a}}$
}

\author{
a Arizona Game and Fish Department, Phoenix, AZ 85086, USA \\ ${ }^{\mathrm{b}}$ United States Department of Agriculture, Wildlife Services, National Wildlife Research Center, Fort Collins, CO 80521, USA \\ ' United States Department of Agriculture, Wildlife Services, National Wildlife Research Center, Predator Research Facility, Logan, UT 84322, USA \\ d Department of Wildland Resources, Utah State University, Logan, UT 84322-5295, USA \\ e Wildlife Conservation Society, North America Program, Bozeman, MT 59715, USA \\ ${ }^{\mathrm{f}}$ Purdue University, Department of Forestry and Natural Resources, West Lafayette, IN 47907, USA
}

\section{A R T I C L E I N F O}

\section{Article history:}

Received 5 April 2011

Received in revised form 7 July 2011

Accepted 1 August 2011

Available online 3 September 2011

\section{Keywords:}

Border fence

Corridor

Genetic connectivity

Landscape connectivity

Ursus americanus

\begin{abstract}
A B S T R A C T
Landscape features such as rivers, mountains, desert basins, roads, and impermeable man-made structures may influence dispersal and gene flow among populations, thereby creating spatial structure across the landscape. In the US-Mexico borderland, urbanization and construction of the border fence have the potential to increase genetic subdivision and vulnerability to isolation in large mammal populations by bisecting movement corridors that have enabled dispersal between adjacent Sky Island mountain ranges. We examined genetic variation in black bears (Ursus americanus) from three regions in central and southern Arizona, US, to assess genetic and landscape connectivity in the US-Mexico border Sky Islands. We found that the three regions grouped into two subpopulations: the east-central subpopulation comprised of individuals sampled in the central highland and high desert regions, and the border subpopulation comprised of individuals sampled in the southern Sky Islands. Occupancy for the border subpopulation of black bears was influenced by cover type and distance to water, and occupancy-based corridor models identified 14 potential corridors connecting border Sky Island habitat cores with the east-central subpopulation. Biological quality of corridors, defined as length:width ratio and proportions of suitable habitat within corridors, declined with Sky Island dispersion. Our results show that black bears in the border subpopulation are moderately isolated from the east-central subpopulation, the main population segment of black bears in Arizona, and that connectivity for border bears may be vulnerable to anthropogenic activities, such as those associated with urbanization and trans-border security.
\end{abstract}

Published by Elsevier Ltd.

\section{Introduction}

Habitat connectivity across a landscape is important to ensuring the persistence of populations through the maintenance of gene flow (Vos et al., 2001), metapopulation dynamics (With et al., 1997), and demographic rescue (Tallmon et al., 2004). Without connectivity, habitat fragmentation constrains animal dispersal and threatens biological diversity (Johnson et al., 1992; Woodroffe and Ginsberg, 1998). Through time, habitat fragmentation yields small isolated populations with elevated extinction probabilities (Lande, 1988; Hanski, 1999). This is particularly true in landscapes where geography leads to spatial structuring of populations, such as large carnivores in the Sky Island (i.e., montane mountain

\footnotetext{
* Corresponding author at: United States Department of Agriculture, Wildlife Services, National Wildlife Research Center, 4101 LaPorte Avenue, Fort Collins, CO 80521, USA. Tel.: +1970266 6054; fax: +1970266 6138.

E-mail address: todd.c.atwood@aphis.usda.gov (T.C. Atwood).
}

ranges) region of the Sonoran and Chihuahuan deserts of southwestern US and northern Mexico.

In human-dominated landscapes, connectivity is often maintained through corridors (Beier and Noss, 1998). Yet corridors may not be sufficient to facilitate population viability if they do not maintain both structural and functional connectivity. Structural connectivity describes the degree to which habitat patches are contiguous or physically linked to one another (With et al., 1997; Tischendorf and Fahrig, 2000), while functional connectivity explicitly incorporates the behavioral responses of animals to describe how both habitat and non-habitat (i.e., matrix) patches influence movement (Taylor et al., 1993; Wiens, 2001). Decreases in patch size and increased isolation may decrease structural connectivity, but if the newly-created matrix patches do not discourage movement, then functional connectivity may remain high (Baguette and Van Dyck, 2007). By contrast, a landscape may be characterized by a high degree of structural connectivity but have diminished functional connectivity as a result of being bisected by a feature that limits movement by creating exceptional risk of 
crossing (e.g., roads, rivers) or acts as a physical impediment (e.g., a fence) (Proctor et al., 2005; Hayward and Kerley, 2009). Detailed information on structural and functional connectivity of corridors is important for predicting their efficacy to conserve wildlife (Beier and Noss, 1998), especially in areas where species already occupy fragmented habitats.

Arizona's desert Sky Island mountain ranges encompass one of the most biologically diverse regions in the United States. Suitable habitat for many of the region's large carnivores, including black bears (Ursus americanus), mountain lions (Puma concolor), and jaguars (Panthera onca) is found in oak woodland and montane habitats separated by lowland desert. Rapid urbanization and the construction of the US-Mexico border fence have the potential to drive genetic subdivision in large mammal populations by severing corridors that historically enabled dispersal between Arizona and Mexico Sky Island ranges (Flesch et al., 2010). Black bears in the region rely heavily on food resources found in these higher elevation montane habitats. The spatial dispersion of montane habitat has likely served to historically subdivide black bear populations, creating detectable genetic structure driven by infrequent, long-distance movements across desert basins (McRae et al., 2005; Onorato et al., 2004). Thus, desert black bears are an ideal candidate for modeling connectivity.

In this study, we integrated landscape genetics with occupancy modeling to assess landscape connectivity for black bears in southern Arizona's desert Sky Islands. Our objectives were to (i) assess genetic connectivity between black bears along the border with Sonora, Mexico, and the main population segment in east-central Arizona, and (ii) identify potential corridors linking core black bear habitats in the border Sky Island ranges. For the former objective, we hypothesized that bears along the border were genetically isolated from east-central bears. For the latter objective, we expected corridor quality to decline as the distance between linked core habitats increased.

\section{Methods}

\subsection{Study areas}

We sampled black bears from several sites in east-central and southern Arizona (Fig. 1). East-central sites were located in the central highlands north of the Mogollon Rim and the high desert immediately south of the Rim, where black bear habitat is relatively continuous (Fig. 1). The central highlands site was contained mostly within the White Mountains of the Apache-Sitgreaves National Forest, approximately $230 \mathrm{~km}$ east of Phoenix, Arizona (Fig. 1). The area was characterized by rugged terrain with steep slopes and deep canyons, an elevational gradient ranging from 1300 to $3000 \mathrm{~m}$, and Rocky Mountain montane and subalpine habitat associations (Brown and Lowe, 1974). Areas above $1700 \mathrm{~m}$ were predominantly comprised of Engelmann spruce (Picea engelmannii) and subalpine fir (Abies lasiocarpa). Douglas fir (Pseudotsuga menziesii), white fir (Abies concolor), and blue spruce (Picea pungens) associations between 2400 and $2750 \mathrm{~m}$; ponderosa pine (Pinus ponderosa), Gambel oak (Quercus gambelii), and aspen (Populus tremuloides) occur at lower-elevations ( $<2400 \mathrm{~m}$ ). The central highlands encompassed a major portion of the watershed providing water to the Phoenix metropolitan area (population 4,192,887) via the Salt and Gila rivers. Yearly precipitation averaged $192 \mathrm{~cm}$, most of which came during the winter as snowfall. Average daily temperatures ranged from $28^{\circ} \mathrm{C}$ in July to $-12{ }^{\circ} \mathrm{C}$ in December (NOAA, Western Regional Climate Center). Predominant land use within the area included timber production, livestock grazing, and recreation. Human population density for the area was $2.39 / \mathrm{km}^{2}$, and housing density was $1.08 /$ $\mathrm{km}^{2}$ (http://quickfacts.census.gov/qfd/states/04000.html; accessed 29 June 2011).
The site south of the Mogollon Rim (hereafter referred to as the Tonto site) was located almost entirely within the Tonto National Forest (Fig. 1). The Tonto site was approximately $81 \mathrm{~km}$ east of Phoenix and $18 \mathrm{~km}$ west of Globe (population 7532), the nearest urban center. Elevations in the area ranged from 700-2300 m, with lower elevations characterized by gently sloping terrain and higher elevations having steep, rocky topography with slopes $>45^{\circ}$ (Cunningham et al., 2003). Primary vegetation at lower elevations was desert scrub and grassland $(<900 \mathrm{~m})$ and interior chaparral (900$1850 \mathrm{~m}$ ) (Brown and Lowe, 1974). Madrean evergreen woodland (e.g., Gamble oak, Emory oak [Quercus emoryi], and ponderosa pine) occurred at higher elevations ( $>1850 \mathrm{~m}$; Brown and Lowe, 1974). Yearly precipitation averaged $63 \mathrm{~cm}$, most of which came during the summer (July and August) monsoons. Average daily temperatures ranged from $37^{\circ} \mathrm{C}$ in July to $-1{ }^{\circ} \mathrm{C}$ in December (NOAA, Western Regional Climate Center). Predominant land use within the area included livestock grazing and recreation. Human population and housing densities were $4.17 / \mathrm{km}^{2}$ and $2.28 / \mathrm{km}^{2}$, respectively, for the greater area (http://quickfacts.census.gov/ qfd/states/04000.html; accessed 29 June 2011).

At the southern site (hereafter referred to as the border site), samples were collected from six Sky Island mountain ranges (i.e., Patagonia and Huachuca [wildland block 3], Whetstone [wildland block 4], Rincon [wildland block 9], Galiuro [wildland block 11], and Chiricahua [wildland block 7] mountains; Fig. 2), north of the border with Sonora, Mexico, and mostly located within the Coronado National Forest. The border site was mostly southeast of the Tucson metropolitan area (population 980,263); the most intensive sample collection occurred in wildland block $3,83 \mathrm{~km}$ southeast of Tucson and directly adjacent to the town of Sierra Vista (population 43,044) and Fort Huachuca military base (Fig. 1). Elevations at the border site ranged from 1300 to $3000 \mathrm{~m}$, with the lowest elevations ( $<1370 \mathrm{~m}$ ) characterized as desert basin primarily comprised of catclaw acacia (Acacia greggii), creosote (Larrea tridentata), and mesquite (Prosopis glandulosa) (Wallmo, 1955). Desert shrub and grassland associations occurred at elevations between 1370 and $1524 \mathrm{~m}$, oak woodlands occurred between 1524 and $2130 \mathrm{~m}$, depending on specific site characteristics, and Madrean evergreen woodland generally occurred at elevations $>1800 \mathrm{~m}$ (Wallmo, 1955). Yearly precipitation averaged $39 \mathrm{~cm}$, most of which came during the summer (July and August) monsoons. Average daily temperatures ranged from $35^{\circ} \mathrm{C}$ in July to $0.5^{\circ} \mathrm{C}$ in December (NOAA, Western Regional Climate Center). Predominant land use for the area includes livestock grazing and recreation. The distribution of black bear habitat at the border site was discontinuous and constrained to Sky Island mountain ranges (Fig. 1). The human population $\left(9.62 / \mathrm{km}^{2}\right)$ and housing densities $\left(3.85 / \mathrm{km}^{2}\right)$ for the greater border area were the highest of the three sampling sites (http://quickfacts.census.gov/qfd/states/04000.html; accessed 29 June 2011).

The Patagonia-Huachuca and Tumacacori (i.e., wildland block 1; Fig. 2) wildland blocks straddled the Arizona-Sonora border, while all other wildland blocks included in connectivity analyses occurred entirely within Arizona. The Patagonia and Huachuca mountains extended approximately $31 \mathrm{~km}$ and $4 \mathrm{~km}$, respectively, into Sonora, with the Patagonia Mountains separated by $7 \mathrm{~km}$ from the northern extent of the large $\left(\approx 5396 \mathrm{~km}^{2}\right)$ Sierra MariquitaSierra de los Ajos mountain range complex (Fig. 2). The Tumacacori wildland block extended $5 \mathrm{~km}$ into Sonora and the southern-most extent was within $7 \mathrm{~km}$ and $19 \mathrm{~km}$, respectively, of the Sierra Cibuta and Sierra de Pinitos mountains (Fig. 2). Vegetation in northern Sonora mirrored that of southern Arizona, with shrub and grassland associations at lower elevations, oak woodlands at mid-elevations, and Madrean evergreen woodlands at higher elevations (Brown, 1994; Bahre and Minnich, 2001). Predominant land use in northern Sonora was livestock grazing (Vasquez-Leon and Liverman, 2004). The international boundary between Arizona and So- 


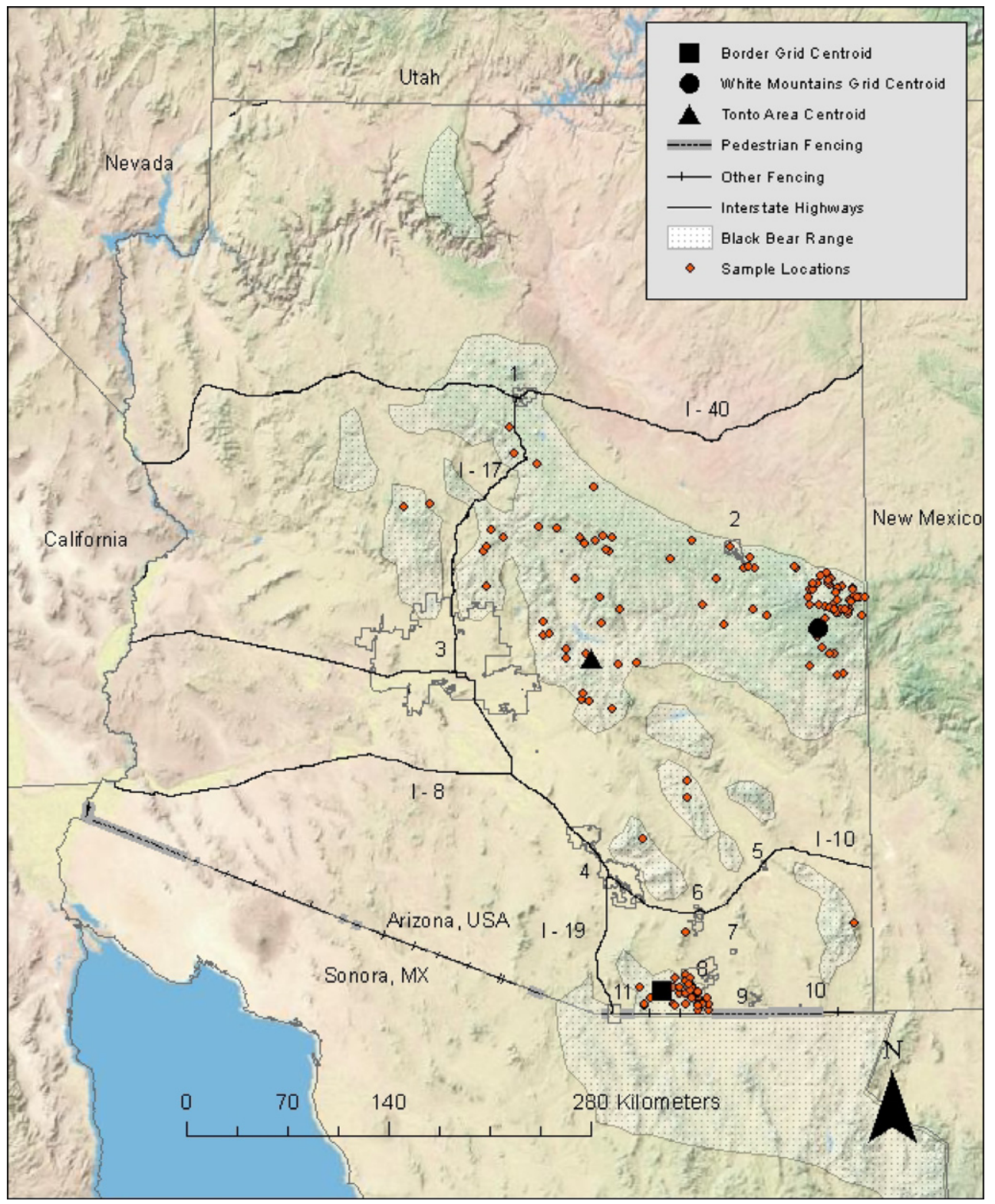

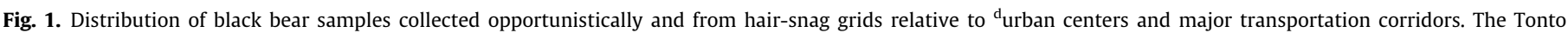

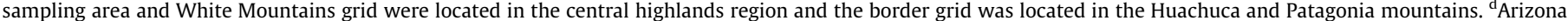

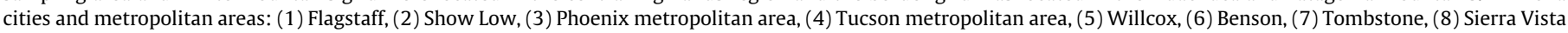
and Ft. Huachuca, (9) Bisbee, (10) Douglas, and (11) Nogales.

nora, Mexico, spans nearly $600 \mathrm{~km}$, approximately $70 \%$ of which was fenced. The type of fence structure varies along the border (Fig. 1). Some segments were $\geqslant 4 \mathrm{~m}$ tall with either no openings or vertical gaps $5-10 \mathrm{~cm}$ wide and thus impermeable to most medium- and large-bodied mammals, while other sections consisted of 4-6 strands of barbed wire coupled with "Normandy style" crossbar vehicle barriers (United States Customs and Border Protection, 2009), and were relatively permeable.

\subsection{Black bear distribution and status in Arizona and Sonora, Mexico}

In Arizona, black bears were classified as a game species and were hunted during the spring and fall. Season lengths and harvest limits varied by game management unit (GMU), with all units being closed for the season when the female harvest approximated
$10 \%$ of the estimated female population in the unit. For GMU in the border sampling area, harvest limits were conservative and generally range from 1-3 females/GMU/yr. Black bears in Mexico were classified as "endangered of extinction" in 1986, and hunting seasons were closed indefinitely (Doan-Crider and Hellgren, 1996). Over the last several decades, the historical distribution of black bears in Mexico is believed to have been reduced by $20 \%$ due to habitat loss, poaching, and illegal trade (Doan-Crider and Hellgren, 1996; Sierra-Corona et al., 2005). Relatively little is known about the status of black bears in Sonora. Sierra-Corona et al. (2005), working in the Sierra de San Luis in northeastern Sonora (Fig. 2; wildland block 21), found that bear density was low compared to similar areas on either side of the border (e.g., Coahuila, Mexico: Doan-Crider, 1995; east-central Arizona: LeCount, 1982), but did not comment on possible reasons. 


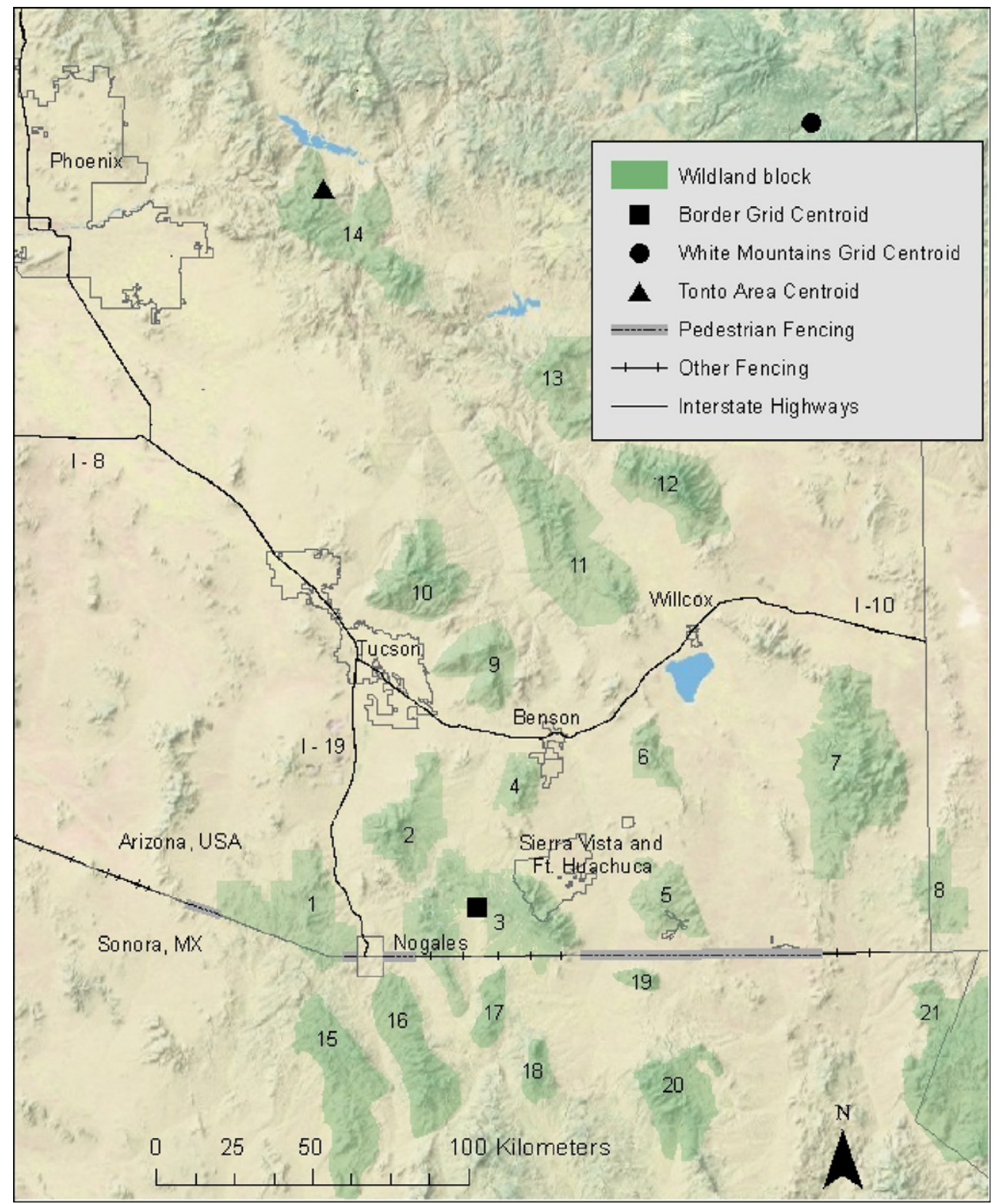

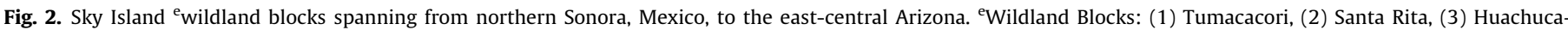

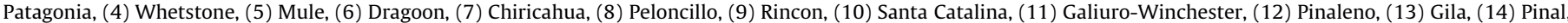
(15) Sierra Cibuta, (16) Sierra Pinito, (17) Sierra Chivato, (18) Sierra Elenita, (19) Sierra San Jose, (20) Sierra Los Ajos, and (21) Sierra San Luis.

\subsection{Sample collection and genetic analyses}

We collected hair samples from black bears using hair-snags and hair and tissue from mandatory hunter check-in. We deployed two hair-snag sampling grids, one at the border site in the Huachuca and Patagonia mountains (i.e., Huachuca-Patagonia grid; wildland block 3), and one in the central highlands (i.e., White Mountains grid) (Fig. 1). The Huachuca-Patagonia and White Mountains grids consisted of 67 and 74 grid cells $(4 \times 4 \mathrm{~km})$, respectively. Sixty-three percent of the Huachuca-Patagonia grid was comprised of evergreen habitat associations, $23 \%$ was desert shrub and grassland, and the remaining 9\% was oak woodland. For the White Mountains grid, 79\% was comprised of evergreen habitat associations, $13 \%$ was montane shrub and grassland, and the remaining $8 \%$ was deciduous woodland. In each cell, we built a hair-snag "corral" by running a single strand of barbed wire at a height of approximately $45 \mathrm{~cm}$ around several trees (Woods et al., 1999). We chose hair-snag locations based on black bear sign, natural travel routes, and forage availability, and maintained a minimum distance of $2 \mathrm{~km}$ between hair-snags located in adjacent cells. We baited the center of corrals with $1 \mathrm{~L}$ of aged fish oil, and ran 3, 10-14 d capture sessions from May through September. The use of a single lure and a standard volume should control for lure-induced heterogeneity in habitat-specific detection probabilities (MacKenzie et al., 2006). We used forceps to collect hair samples from barbs, stored individual samples in tooth envelopes, and flamed barbs to prevent cross-contamination. Samples also were obtained at the high desert site from hair-snags located in the Tonto National Forest that were independently deployed and operated by Arizona Game and Fish Department (AGFD) personnel (Fig. 1). The Tonto hair-snags were deployed opportunistically rather than in a grid-design, which precluded their use in estimating a site density.

We extracted DNA from samples using a Qiagen DNeasy Blood and Tissue Kit (Qiagen) employing an ammonium acetate protocol (modified from the PUREGENE kit; Gentra Systems). We used a set 
of 11 microsatellite loci known to amplify in black bears (G10J, G10M, G10X, G10B, G10H, G10C, G10L, G1D, G1a, UarMu50, UarMu59; Paetkau et al., 1995, 1998) grouped into three sets based on product size and primer label. Each set of loci was amplified together in the same Polymerase Chain Reaction (PCR) in $10 \mu \mathrm{L}$ PCRs using a Master-cycler ep gradient (Eppendorf) and $3 \mu \mathrm{L}$ of template DNA, $0.2 \mathrm{mM}$ of each dNTP, $0.2 \mathrm{M}$ to $0.4 \mathrm{M}$ of each primer pair, $1 \mathrm{U}$ of Taq DNA polymerase (NEB), $1.25 \mathrm{mM} \mathrm{MgCl}_{2}$ and $2 \times$ reaction buffer ( $10 \mathrm{mM}$ Tris- $\mathrm{HCl}, 50 \mathrm{mM} \mathrm{KCl}, 0.05 \mathrm{mg} / \mathrm{mL} \mathrm{BSA}$ ). Amplification conditions were $94^{\circ} \mathrm{C}$ for $2 \mathrm{~min}$, then $94{ }^{\circ} \mathrm{C}$ for $30 \mathrm{~s}, 60^{\circ} \mathrm{C}$ for $30 \mathrm{~s}, 72{ }^{\circ} \mathrm{C}$ for $30 \mathrm{~s}$ for 35 cycles, then $72{ }^{\circ} \mathrm{C}$ for $10 \mathrm{~min}$ and a final extension at $60{ }^{\circ} \mathrm{C}$ for $45 \mathrm{~min}$. Multiplexed reactions were combined with an internal lane size standard and electrophoresed through a capillary gel matrix using an ABI 3730 Automated DNA Sequencer. Allele sizes were determined for each locus using GeneMapper software v3.7 (Applied Biosystems).

We ran positive and negative controls within each genotyping set and included an individual of known genotype at each locus within every sample set analyzed to maximize quality and consistency of genotyping. Each sample was amplified repeatedly until 3 matching genotypes were obtained at each locus within each individual, or until we ran out of DNA, to avoid errors associated with DNA collected with non-invasive methods (Taberlet et al., 1996, 1999; Kohn and Wayne, 1997). This resulted in the generation of at least three multilocus genotypes for each sample.

For sex determination, a fragment of the amelogenin gene was amplified using the primers SE47 and SE48 (Ennis and Gallagher, 1994). The amplification conditions were similar to those used for the microsatellites except the annealing temperature was $64^{\circ} \mathrm{C}$ and the annealing and extension times were decreased to 15 s per cycle. PCR products were run on a $2 \%$ agarose gel stained with ethidium bromide. Samples were scored as female if they exhibited one band and males if there were two bands. DNA samples extracted from the tissues of known-sex harvested black bears were used as controls for our sexing assessments.

The program GIMLET (Valiere, 2002) was used to generate a consensus multilocus genotype for each sample and to identify matching multilocus genotypes among samples. Samples with genotypes for at least 6 loci were retained in the dataset; loci that did not have three matching genotypes were scored as "missing data." Only unique multilocus genotypes were included in subsequent analyses of basic population genetic parameters for the overall dataset. We calculated the number of alleles per locus, observed heterozygosity $\left(H_{\mathrm{O}}\right)$, and expected heterozygosity $\left(H_{\mathrm{E}}\right)$ for each locus using GDA (version 1.1, Lewis and Zaykin, 1999). Tests for linkage disequilibrium and deficiencies of heterozygotes relative to Hardy-Weinberg expectations for each locus and globally were performed using the program GENEPOP (version 3.4; Raymond and Rousset, 2000). We employed two Bayesian clustering software programs, STRUCTURE (version 2.2, Pritchard et al., 2000) with the $\Delta \mathrm{K}$ method (Evanno et al., 2005) and GENELAND (version 3.1.4, Guillot et al., 2005b), to infer the number of subpopulations in our dataset and assign individuals to those subpopulations. All samples with unique multilocus genotypes were used in the STRUCTURE analysis, whereas only those samples with both unique multilocus genotypes and spatial coordinates were used in the GENELAND analysis.

In STRUCTURE we performed five runs at each value of $K$ (the number of subpopulations) from $K=1$ to $K=10$. Each run consisted of 100,000 replicates of the MCMC after a burn-in of 30,000 replicates. We used the admixture model and allowed the allele frequencies to be correlated among subpopulations. To assign individuals to subpopulations, a final run (100,000 burn-in and 500,000 replicates) at the inferred $\mathrm{K}$ was performed. The values of $q$, which are indicative of the proportion of an individual's genome characteristic of each subpopulation, were used to assign indi- viduals. Individuals were considered unambiguously assigned to a subpopulation when $q$ values were greater than 0.75 . When $q$ values were less than 0.75 , assignments of individuals were distributed among multiple subpopulations. To infer the number of subpopulations $(K)$ in GENELAND, we first varied the number of subpopulations from 1 to 5 using 5000 stored MCMC iterations $(200,000$ iterations, thinning $=40)$. We set the maximum rate of the Poisson process to 100 (a value close to the number of individuals in our data set) and the maximum number of nuclei to 300 ( $3 *$ maximum rate as suggested by Guillot et al., 2005a). We ran the GENELAND MCMC 10 times with the level of uncertainty attached to our spatial coordinates set to $2 \mathrm{~km}$. We used the mode of the distribution of $K$ as a point estimate of $K$. The assignment of individuals to subpopulations was performed in a separate run as suggested by Guillot et al. (2005a). For this run, $K$ was set to the inferred number of subpopulations and all other parameters were similar to those runs with variable $K$. The posterior probability of subpopulation membership was computed for each pixel of the spatial domain $(50 \times 50$ pixels), using a burn-in of 1000 iterations. Individuals with a posterior probability of population membership of greater than 0.75 were unambiguously assigned to that subpopulation.

For each subpopulation inferred in either STRUCTURE or in GENELAND, levels of genetic diversity were estimated by calculating the average number of alleles per locus, observed heterozygosity $\left(H_{\mathrm{O}}\right)$, expected heterozygosity $\left(H_{\mathrm{E}}\right)$, fixation index, and the number and frequency of unique alleles using GDA. We estimated the levels of genetic differentiation among the inferred subpopulations by calculating $\mathrm{F}_{\mathrm{ST}}$ in GDA. Significance of each $\mathrm{F}_{\mathrm{ST}}$ value was based on $95 \%$ confidence intervals determined by bootstrapping across all loci, where confidence intervals bracketing zero indicate no evidence of genetic variance partitioning between sample subset pairs. Average relatedness of individuals within each subpopulation was assessed using Wang's (2002) estimator in SPAGeDi (Hardy and Vekemans, 2002).

The program CAPWIRE (Miller et al., 2005) was used to estimate population size within the Huachuca-Patagonia and White Mountains grids. We set the maximum population size to 100 for the Huachuca-Patagonia grid and 400 for the White Mountains grid, and used the likelihood ratio test (LRT) to determine which capture probability model was most accurate. Two capture models are available: the even capture probability model (ECM) where every individual is equally likely to be captured and the two innate rates model (TIRM) where individuals do not display equal capture probabilities. The appropriate model, based on LRT, was then used to estimate population size for each of the two grids.

\subsection{Occupancy and landscape modeling}

For occupancy analyses, our objective was to determine if bear occupancy $(\psi)$ at the border hair-snag grid (i.e., Huachuca and Patagonia mountains) differed relative to habitat type and landscape covariates. We used the occupancy model option in program MARK (White and Burnham, 1999) to estimate occupancy relative to land cover (Madrean evergreen woodland [MEW], mixed conifer woodland [MXC], semi-desert grassland [DG], plains and Great Basin grassland [GBG], and oak woodland [OW]), slope $\left({ }^{\circ}\right)$, aspect, elevation $(m)$, and distances to permanent water and roads $(m)$. We used point extraction and Euclidean distance routines in a 30-m resolution (i.e., USGS Seamless Server NED data) GIS to collect information on land cover and landscape covariates for hair-snag locations. We tested for collinearity among potential variables by examining tolerance and variance inflation factors (VIF) using weighted least squares regression, and excluded variables with tolerance scores $<0.4$ from analyses (Allison, 1999). 
We formulated 12 models and kept the detection probability $(p)$ constant, assuming it did not vary across time or habitat types and was not influenced by individual covariates. We modeled occupancy $(\psi)$ with and without a habitat effect (i.e., group effect) or individual covariates. We used the variance inflation factor (i.e., c-hat in MARK) to guard against overdispersion and the small sample size correction of Akaike's Information Criterion (QAICc). C-hat was calculated using the median c-hat procedure in program MARK. In addition to reporting model selection results, we also reported the beta parameter and 95\% confidence interval for the covariates and evaluated whether or not the beta parameter overlapped zero and used this as further evidence of the significance of each individual covariate for modeling occurrence of bears. We calculated model-averaged occupancy values and 95\% confidence intervals for the model averaged parameters following procedures in program MARK.

Corridor modeling involved four steps: (i) creating a habitat suitability model; (ii) identifying breeding- and population-size patches within Sky Island wildland blocks (i.e., polygons estimating the areal extent for each Sky Island range; Fig. 1); (iii) creating a cost surface representing the grid cell resistance to movement; and (iv) applying a cost-distance routine to identify pixel swaths (i.e., corridors) linking wildland blocks. We used the results of the border occupancy model to parameterize a habitat suitability model (HSM) for the composite sampling region (i.e., 15 mountain ranges [four of which were combined into two wildland blocks] comprising the sky island complex and 1 mountain range [Pinal Mountains; wildland block 14] representing the southern extent of the high desert sampling region; Fig. 2). The HSM was comprised of grid layers representing land cover, elevation, aspect, slope, distance to water, and distance to road. For all grids we reclassified pixel values using the results from the occupancy models. Distances to road and water were weakly correlated (i.e., tolerance $<0.4$ ), but because it has been documented that bears avoid roads (e.g., Brody and Pelton, 1989), we included a reclassified road grid in our HSM.

We reclassified the land cover grid by collapsing 35 landcover classes from the 2001 National Landcover Data (NLCD) set (e.g., Encinal oak woodland) into five broader categories (e.g., oak woodland) and assigning the latter a value from 0 (absolute non-habitat) to 100 (optimal habitat) based on detection probabilities scaled from occupancy models (Table 1). For the elevation, aspect, and distances to water and roads grids, we created $5,4,3$, and 3 evenly-spaced bins, respectively, and assigned values (0-100) based on probabilities of occurrence at hair-snag stations (Table 1). Slope often is modeled as a discrete value for individual grid pixels. While convenient, that practice may fail to capture neighborhood permeability thresholds that can occur in a rugged landscape, such as the Sky Island region. Accordingly, we used a moving window analysis in a GIS where we characterized the topographic position of a given pixel relative to adjacent pixels found within a $200-\mathrm{m}$ radius. Using this method, we classified pixels as canyon bottom if the focal pixel elevation was at least $12 \mathrm{~m}$ less than the neighborhood average, a ridge-top if the pixel elevation was at least $12 \mathrm{~m}$ greater than the neighborhood average, a gentle slope if the pixel was neither a canyon bottom nor a ridge-top and had a slope $<6^{\circ}$, and a steep slope if the pixel was neither a canyon bottom nor a ridge-top and had a slope $>6^{\circ}$. The resulting topographic position index (TPI) grid was then reclassified following the method used for the elevation grid but using three bins. Finally, we combined the six individual grids using a weighted geometric mean algorithm (Table 1) where individual grid weighting factors were scaled to their proportional contribution based on the model-averaged Akaike weights.

We used the HSM to identify contiguous areas of suitable habitat that could function as breeding- and population-size patches
Table 1

Grid layers and variables, reclassified grid cell values, weighting factors used to assemble the habitat suitability model for the Arizona border Sky Islands.

\begin{tabular}{|c|c|c|}
\hline Variable & Reclassified cell value & Weighting factor \\
\hline Land cover type & & 0.50 \\
\hline Madrean evergreen & 100 & \\
\hline Mixed conifer & 68 & \\
\hline Oak woodland & 84 & \\
\hline Semi-desert grassland & 56 & \\
\hline Plains and Great Basingrassland & 1 & \\
\hline Distance to water & & 0.35 \\
\hline$<500 \mathrm{~m}$ & 100 & \\
\hline $500-1000 \mathrm{~m}$ & 50 & \\
\hline$>1000 \mathrm{~m}$ & 25 & \\
\hline Distance to roads & & 0.05 \\
\hline$<500 \mathrm{~m}$ & 25 & \\
\hline $500-1250 \mathrm{~m}$ & 50 & \\
\hline$>1250 \mathrm{~m}$ & 100 & \\
\hline Aspect & & 0.04 \\
\hline North & 80 & \\
\hline East & 35 & \\
\hline South & 100 & \\
\hline West & 25 & \\
\hline Elevation & & 0.03 \\
\hline$>763 \mathrm{~m}$ & 20 & \\
\hline $163-1219 \mathrm{~m}$ & 37 & \\
\hline $1220-1981 \mathrm{~m}$ & 100 & \\
\hline $1982-2591 \mathrm{~m}$ & 81 & \\
\hline $2592-4000 \mathrm{~m}$ & 63 & \\
\hline Topographic position & & 0.03 \\
\hline Canyon bottom & 50 & \\
\hline Gentle slope & 100 & \\
\hline Ridge top & 25 & \\
\hline
\end{tabular}

within wildland blocks. Based on previous black bear work conducted in Arizona, we selected a minimum breeding patch size of $50 \mathrm{~km}^{2}$ and extrapolated a minimum population patch $(n=50$ bears) size of $300 \mathrm{~km}^{2}$ (LeCount, 1982). We used a moving window analysis (200-m radius) in a GIS to group together pixels with a suitability value of $\geqslant 60$ into the breeding and population patches. We chose the $200-\mathrm{m}$ radius to depict suitability relative to the landscape pattern and the spatial requirements and perceptual ability of black bears (Vos et al., 2001). The Sky Island landscape is relatively patchy in nature, owing to the basin and range topography, and the window analysis must be fine enough to detect changes in patch quality at a scale that bears are likely to perceive (Lima and Zollner, 1996). Cunningham and Ballard (2004) found that the home ranges of female black bears in central Arizona's Sky Islands averaged $13 \mathrm{~km}^{2}$. Our $200-\mathrm{m}$ radius equates to a 12.6 ha neighborhood, which is approximately one-tenth the area of the average female home range, and should represent a patch size that bears can detect.

We converted the HSM into a cost surface by calculating cell resistance (i.e., travel cost; cell resistance $=100$ - pixel suitability) for the entire grid. The resulting cost surface grid was comprised of pixel values that reflected the cost of (or resistance to) movement through each individual grid cell, with increasing cell values representing increasing resistance to movement. We then applied a moving window analysis (200-m radius) to generate corridor models (pixel swaths) that connected habitat cores while minimizing resistance to movement. We selected the best biological corridors (e.g., Bennett et al., 1994) based on the pixel swath that minimized within-swath gaps, maximized within-swath habitat suitability, and reduced edge effects by maintaining a minimum width equal to the radius of an estimated home range (LeCount, 1982; Cunningham and Ballard, 2004). All habitat and corridor modeling was done using the CorridorDesigner package for ArcGIS (Majka et al., 2007). 
Table 2

Characterization of the 11 microsatellite loci used in genetic analyses of black bears sampled at central highlands and border sites in Arizona, 2007-2008. Number of samples genotyped $(N)$, number of alleles per locus $(A)$, expected $\left(H_{\mathrm{E}}\right)$ and observed $\left(H_{\mathrm{O}}\right)$ heterozygosities and the fixation index are reported.

\begin{tabular}{lllllr}
\hline Locus & $N$ & $A$ & $H_{\mathrm{E}}$ & $H_{\mathrm{O}}$ & \multicolumn{1}{l}{$f$} \\
\hline G10J & 157 & 7 & 0.679 & 0.637 & 0.062 \\
G10M & 155 & 5 & 0.692 & 0.587 & $0.152^{\mathrm{a}}$ \\
G10X & 157 & 6 & 0.548 & 0.580 & -0.057 \\
G10B & 151 & 7 & 0.559 & 0.556 & 0.072 \\
G10H & 157 & 10 & 0.484 & 0.510 & -0.052 \\
G1D & 158 & 7 & 0.743 & 0.684 & $0.081^{\mathrm{a}}$ \\
UarMu50 & 157 & 3 & 0.126 & 0.083 & $0.343^{\mathrm{a}}$ \\
G10C & 156 & 4 & 0.329 & 0.346 & -0.051 \\
G10L & 157 & 8 & 0.815 & 0.790 & 0.031 \\
G1A & 156 & 6 & 0.192 & 0.186 & 0.034 \\
UarMu59 & 148 & 6 & 0.663 & 0.635 & 0.042 \\
All & 155.36 & 6.27 & 0.534 & 0.508 & 0.048 \\
\hline
\end{tabular}

a Significant heterozygote deficiency $(\alpha=0.05)$.

\section{Results}

\subsection{Genetic connectivity}

Samples for genetic analyses were distributed over $\approx 31,250 \mathrm{~km}^{2}$ in the east-central region and collected from six Sky Island mountain ranges (Fig. 1). For the White Mountains hair-snag grid, samples were collected from $43 \%$ of grid cells, with $35 \%$ of those hair-snags yielding samples from $\geqslant 2$ capture sessions. Similarly, samples were collected from $40 \%$ of grid cells at the border hair-snag grid, with $46 \%$ of those hair-snags yielding samples from $\geqslant 2$ capture sessions. We were able to obtain usable multilocus genotypes for 189 of the 258 samples. Of these 189 multilocus genotypes, 158 were identified by GIMLET as being unique. Of these 158 individuals, 52 were female and 96 were male (10 of unknown sex). For the pooled sample, the overall number of alleles per locus ranged from 3 (UarMu50) to 10 (G10H) and observed single locus heterozygosities ranged from 0.083 (UarMu50) to 0.790 (G10L) (Table 2). Global tests of the pooled dataset revealed an overall significant deviation from Hardy-Weinberg equilibrium $(P=0.003)$ and significant deficiencies of heterozygotes at three individual loci were observed, which is not unexpected if there is underlying population subdivision within the pooled dataset (Table 2). Linkage disequilibrium was observed between three pairs of loci (G1D-G10B, G1D-G10L and G1D-G10 J) after a sequential Bonferroni correction $(\alpha=0.00019)$. Assuming matching multilocus genotypes indicate re-captures, 138 bears were captured only once, 13 bears were captured twice, four were captured three times, two were captured four times, and one was captured five times. In each instance where the data indicated that a bear was recaptured multiple times, all recaptures for that individual occurred within the same grid used for population estimation or within the set of individuals that could not be assigned to a grid. In only four instances did the multilocus genotypes of pairs of unique individuals differ at less than three loci.

STRUCTURE and the $\Delta K$ measure indicated the most likely number of subpopulations $(K)$ was 3 (Fig. 3a); however at $K=3$ few individuals were assigned to any of the three subpopulations with high certainty. When $K=2$, most individuals were unambiguously assigned to one of two subpopulations (Fig. 3b). These two subpopulation groupings roughly corresponded to the east-central ( $n=102$; 62 males, 38 females, 2 unknown sex) and border $(n=33 ; 17$ males, 11 females, 5 unknown sex) regions. Twenty- (a)

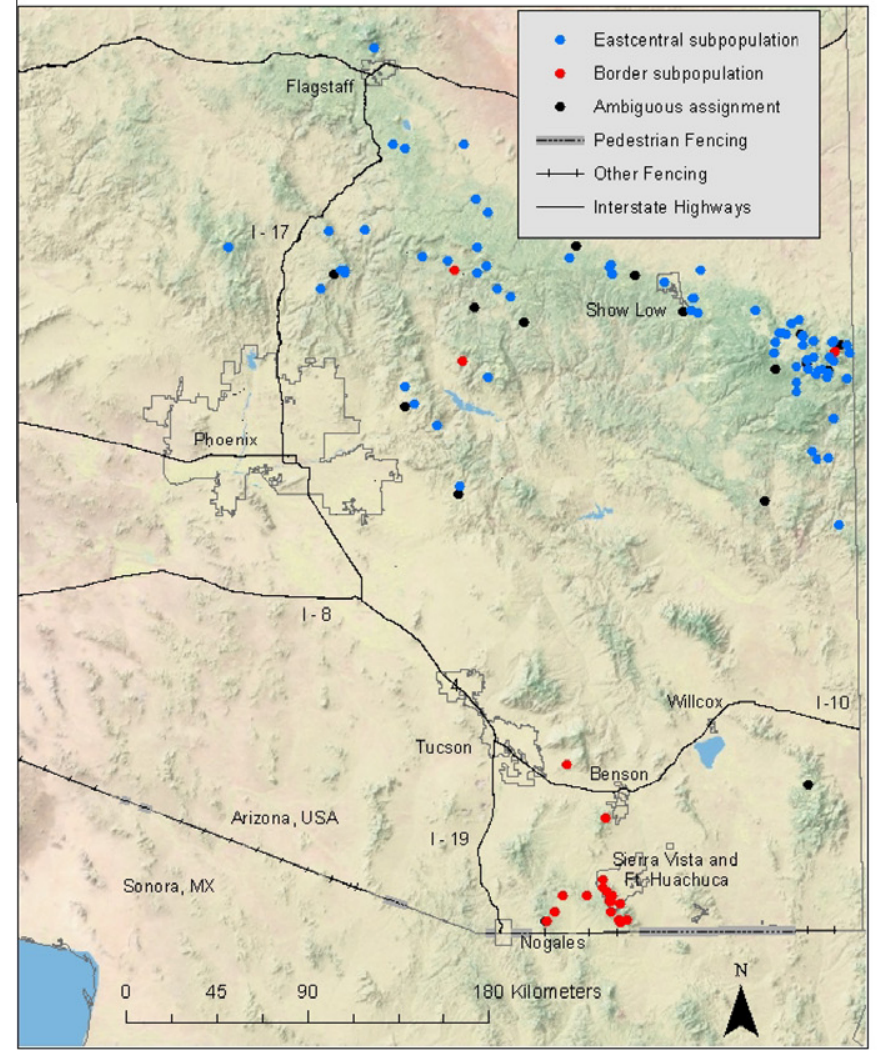

(b)

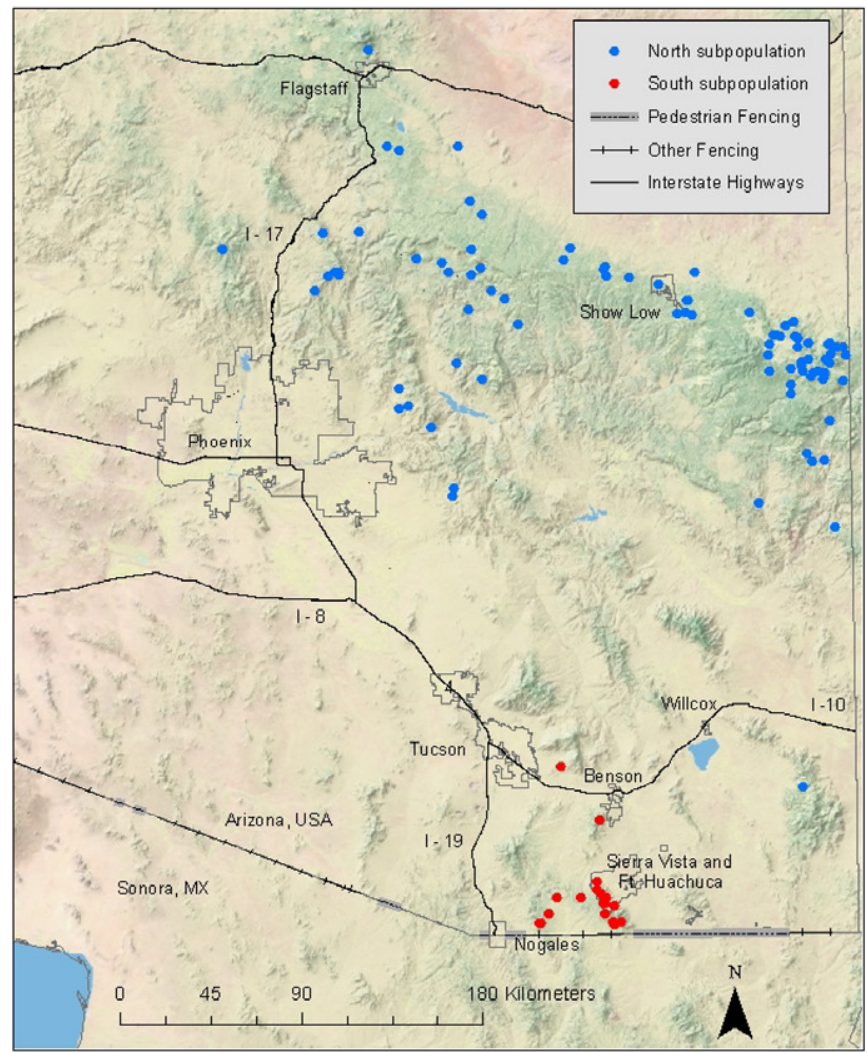

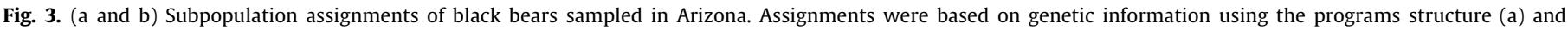
Geneland (b). 
Table 3

Estimates of genetic diversity for the two subpopulations identified from black bears sampled at central highlands and border sites in Arizona, 2007-2008. Number of samples genotyped $(N)$, average number of alleles per locus $(A)$, expected $\left(H_{\mathrm{E}}\right)$ and observed $\left(H_{\mathrm{O}}\right)$ heterozygosities, fixation index $(f)$ values, and $\left(F_{\mathrm{st}}\right)$ are reported.

\begin{tabular}{lllllll}
\hline Population & $N$ & $A$ & $H_{\mathrm{E}}$ & $H_{\mathrm{O}}$ & $f$ & $F_{\text {st }}$ \\
\hline Overall & 158 & 6.3 & 0.534 & 0.508 & 0.048 & $\mathrm{NA}$ \\
East-central $^{\mathrm{a}}$ & 102 & 5.8 & 0.541 & 0.538 & 0.006 & 0.111 \\
Border $^{\mathrm{a}}$ & 33 & 4.3 & 0.432 & 0.422 & 0.023 & \\
East-central $^{\mathrm{b}}$ & 113 & 6.2 & 0.540 & 0.534 & 0.011 & 0.113 \\
Border $^{\mathrm{b}}$ & 28 & 3.9 & 0.411 & 0.401 & 0.024 & \\
\hline
\end{tabular}

a Subpopulations assigned by STRUCTURE. Twenty-three bears with ambiguous assignments were removed from the dataset.

b Subpopulations assigned by GENELAND.

three individuals (17 males, 3 females, 3 unknown sex) were assigned to both subpopulations ( $q$ values less than 0.75 ): 19 of the individuals were from the central highlands area, 3 were from the high desert area, and one was from the border area. These ambiguously assigned individuals were not included in the subsequent genetic or demographic analyses of the inferred subpopulations. Similar levels of genetic diversity were observed within each of the two subpopulations defined by STRUCTURE (Table 3). There were large numbers of unique alleles in the east-central subpopulation $(n=22)$ compared to the border subpopulation $(n=5)$. Most unique alleles were at low frequency, however at 1 locus (G1D in the border subpopulation) a unique allele was observed at a frequency of $41 \%$. Significant genetic differentiation was observed between the two inferred subpopulations $\left(F_{\mathrm{ST}}=0.111 ; 95 \% \mathrm{CI}\right.$ : $0.056-$ $0.156 ; n=135$; Table 3 ). Average relatedness estimates of individuals within subpopulations were 0.16 and 0.37 in the central highlands and border subpopulations, respectively.

The GENELAND analysis indicated that the most likely number of subpopulations was 2. Through the incorporation of spatial coordinates, GENELAND was able to identify a northern subpopulation ( $n=113,70$ males, 37 females, 6 unknown sex) and a southern subpopulation ( $n=28,15$ males, 10 females, 3 unknown sex) which corresponded to the east-central and border regions of our study. All individuals were unambiguously assigned to one of the two subpopulations. Similar levels of genetic diversity were observed within each of the two subpopulations defined by GENELAND (Table 3 ). There were large numbers of unique alleles in the east-central subpopulation $(n=26)$ compared to the border subpopulation $(n=1)$, however most unique alleles were at low frequency. Significant genetic differentiation was observed between the two inferred subpopulations $\left(F_{\mathrm{ST}}=0.113 ; 95 \% \mathrm{CI}\right.$ : 0.051-0.167; Table 3). Average relatedness estimates of individuals within subpopulations were 0.16 and 0.41 in the east-central and border subpopulations, respectively.
Table 5

Occupancy $(\psi)$ estimates of black bears in different habitat types at Border study site in Arizona. Estimates were generated in program MARK by model averaging values of $\psi$ over the suite of candidate models presented in Table 4

\begin{tabular}{lllll}
\hline Habitat type & $\psi$ & SE & Lower95\% CI & Upper95\% CI \\
\hline Madrean evergreen (MEW) & 0.72 & 0.10 & 0.50 & 0.87 \\
Mixed conifer (MXC) & 0.55 & 0.17 & 0.25 & 0.83 \\
Desert grassland (DG) & 0.45 & 0.25 & 0.10 & 0.86 \\
Great Basin grassland (GBG) & 0.10 & 0.23 & 0.001 & 0.94 \\
Oak woodland (OW) & 0.71 & 0.14 & 0.39 & 0.90 \\
\hline
\end{tabular}

The LRT in CAPWIRE identified the TIRM as most appropriate capture probability model for data from the White Mountains grid and estimated the population size to be 252 bears (95\% CI: $137-$ 396). The ECM was identified as most appropriate capture probability model for data from the Huachuca-Patagonia grid and population size was estimated to be 69 bears (95\% CI: 39-82).

\subsection{Occupancy and connectivity modeling}

For the border data set we estimated probability of detection to be 0.79 ( $\mathrm{SE}=0.04)$ and found strong evidence that occupancy differed between habitat types and that distance to water (disw) from hair-snags influenced estimates of occupancy $(\psi)$. Models with a habitat effect (group effect) accounted for $85 \%$ of the weight (Table 4) and the individual covariate "disw" was in the top two models (accounting for $61 \%$ of the model weight), and was the only covariate whose $95 \%$ confidence interval around the beta value did not overlap zero (Table 4). Occupancy estimates ranged between 0.72 and 0.10 between habitat types with occupancy highest in MEW followed by OW, MXC, DG and GBG (Table 5). Variance was highest for DG and GBG indicating high levels of uncertainty in our estimates of occupancy for these habitat types. The relationship between distance to water and occupancy was negative.

The habitat suitability model identified population- and breeding-size patches of suitable and optimal habitat in all Sky Island wildland blocks (Fig. 4). Along the border, the greatest area of population- and breeding-size patches was found in the Chiricahua block (block 7; $923 \mathrm{~km}^{2}$ ), followed by the Huachuca-Patagonia (block 3; $831 \mathrm{~km}^{2}$ ), and Santa Rita (block 2; $481 \mathrm{~km}^{2}$ ) blocks (Fig. 4). The Dragoon Mountains block was the smallest and had the least amount of suitable habitat (Fig. 4, block 6; $307 \mathrm{~km}^{2}$ ). Isolation of wildland blocks generally increased from west to east, with the shortest nearest neighbor distances occurring between the Huachuca-Patagonia and Santa Rita blocks followed closely by the Huachuca-Patagonia and Tumacacori blocks.The structural and qualitative characteristics of potential corridors connecting

Table 4

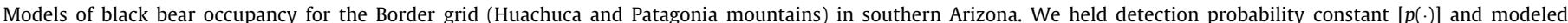

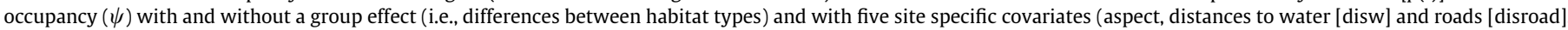

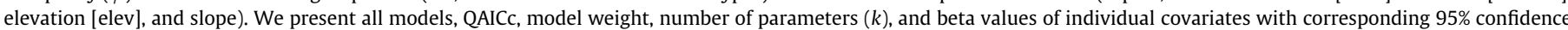
intervals. Cells shaded gray had beta values with $95 \%$ confidence intervals not overlapping zero, providing evidence of significance.

\begin{tabular}{|c|c|c|c|c|c|c|}
\hline Model & QAICC & Model weight & $k$ & Covariate beta value & Lower95\% CI & Upper95\% CI \\
\hline $\mathrm{p}(\cdot) \psi[$ (group) + (water) $]$ & 198.7 & 0.45 & 7 & -0.003 & -0.006 & -0.0001 \\
\hline $\mathrm{p}(\cdot) \psi[(\cdot)+($ water $)]$ & 200.8 & 0.16 & 3 & -0.004 & -0.006 & -0.001 \\
\hline $\mathrm{p}(\cdot) \psi($ group) & 200.9 & 0.15 & 6 & $\mathrm{n} / \mathrm{a}$ & & \\
\hline $\mathrm{p}(\cdot) \psi[$ (group) $+($ road $)]$ & 202.3 & 0.08 & 7 & 0.001 & -0.001 & 0.002 \\
\hline $\mathrm{p}(\cdot) \psi[$ (group) + (aspect) $]$ & 202.5 & 0.07 & 7 & 0.003 & -0.003 & 0.009 \\
\hline $\mathrm{p}(\cdot) \psi[($ group $)+($ slope $)]$ & 203.3 & 0.05 & 7 & -0.005 & -0.086 & 0.075 \\
\hline $\mathrm{p}(\cdot) \psi[($ group $)+($ elev $)]$ & 203.3 & 0.05 & 7 & -0.00002 & -0.002 & 0.002 \\
\hline $\mathrm{p}(\cdot) \psi(\cdot)$ & 210.2 & 0.00 & 2 & $\mathrm{n} / \mathrm{a}$ & & \\
\hline $\mathrm{p}(\cdot) \psi[(\cdot)+(\operatorname{road})]$ & 210.4 & 0.00 & 3 & 0.0006 & -0.0003 & 0.002 \\
\hline $\mathrm{p}(\cdot) \psi[(\cdot)+(\mathrm{elev})]$ & 211.3 & 0.00 & 3 & -0.0004 & -0.0004 & 0.001 \\
\hline $\mathrm{p}(\cdot) \psi[(\cdot)+($ aspect $)]$ & 212.2 & 0.00 & 3 & 0.001 & -0.004 & 0.006 \\
\hline $\mathrm{p}(\cdot) \psi[(\cdot)+($ slope $)]$ & 212.2 & 0.00 & 3 & 0.013 & -0.051 & 0.076 \\
\hline
\end{tabular}




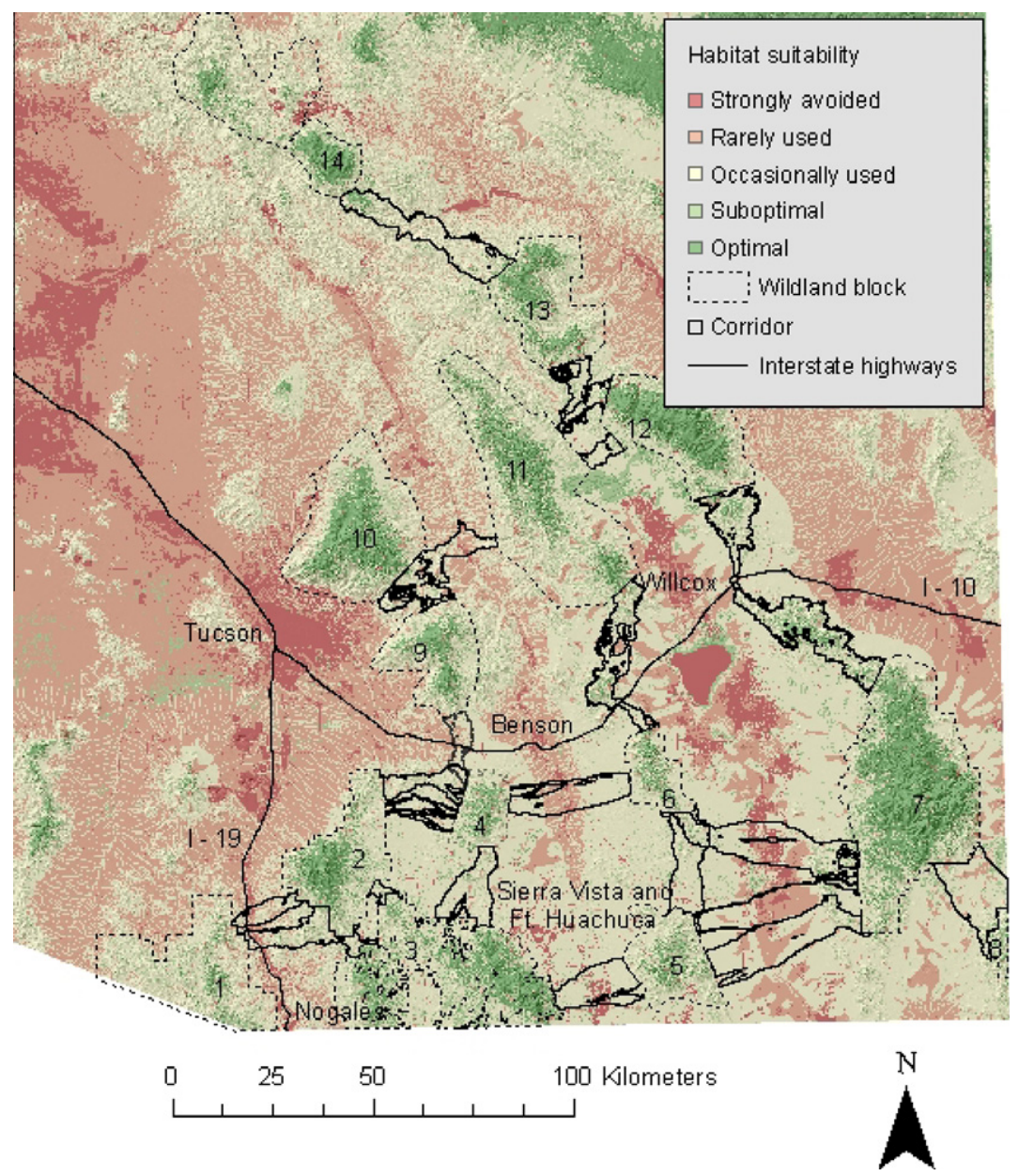

Fig. 4. Habitat suitability map for the area encompassing the Arizona Sky Island wildland blocks and corridors.

the eight border Sky Islands (wildland blocks 1-8; Fig. 5) differed greatly, but generally the western-most wildland blocks (i.e., Tumacacori [1], Santa Rita [2], Huachuca-Patagonia [3], and Whetstone [4] blocks) were connected by higher quality corridors. For these corridors, length to narrowest width ratios averaged $\leqslant 4.4: 1$ (range: $1.11: 1-9.0: 1 ; \mathrm{SE}=0.95$ ), with $\geqslant 1$ corridor within each of the individual linkages containing $\geqslant 57 \%$ suitable (either optimal or suboptimal) habitat (Fig. 4). By contrast, the mean length to width ratios of the corridors connecting the eastern-most wildland blocks (i.e., Mule [5], Dragoon [6], Chiricahua [7], and Peloncillo [8] blocks) was $6.8: 1$ (range: $1.2: 1-12.1: 1$; $S E=1.11$ ), and only 1 linkage (Dragoon-Mule mountains corridor) contained $>57 \%$ suitable habitat (Fig. 4). The linkages connecting the Huachuca-Patagonia and Mule, Whetstone and Mule, Dragoon and Chiricahua, and Mule and Chiricahua blocks all contained $<57 \%$ suitable habitat and spanned 23-44 km over desert basin habitat (Fig. 5). Corridors connecting the northernmost wildland blocks (blocks 9-14; Fig. 5) were generally of similar suitability to the western-most border wildland blocks in that all contained $>57 \%$ of optimal or suboptimal habitat (Fig. 4), but length to width ratios were more variable $(\bar{x}=4.7: 1$; range: $1.0: 1-17.0: 1 ; \mathrm{SE}=2.08)$.

\section{Discussion and conclusions}

Our study revealed several important findings regarding black bear genetic and landscape connectivity in Arizona. First, we detected significant genetic differentiation between black bears sampled in the border region and those sampled in the high desert and central highlands regions. Second, based on density estimates derived from the White Mountains and Huachuca-Patagonia hairsnag grids, the border subpopulation density $\left(0.06 \mathrm{bear} / \mathrm{km}^{2}\right)$ was substantially lower than the east-central subpopulation $(0.21$ bear $/ \mathrm{km}^{2}$ ). Although our grid-based density estimates relate only to the area covered by the grids, the bio-physical characteristics of grids were very similar to their respective regions (Brown, 1994). Accordingly, we believe the estimated grid densities approximate densities across sampling regions. Finally, while the border Sky Island mountain ranges do provide adequate amounts of suitable habitat to support black bears, there is wide variation in the biological quality of corridors that connect them. While black bears are not a species of concern in US, they are in Mexico, which represents the southern extent of their historic and current range (Pelton et al., 1998). Given the above, black bear persistence in the US-Mexico border Sky Islands may be particularly vulnerable to further loss of habitat due to urbanization and border security activities.

Black bear populations in Arizona exhibit a north-south spatial structure in which the border sub-population is isolated from, and less genetically diverse than, the main population segment in eastcentral Arizona. These patterns are likely the result of both historic and contemporary impediments to individual movement and thus gene flow (McRae et al., 2005). For example, the harsh environment and dispersion of suitable montane habitat patches in a desert basin matrix have previously been implicated as historic impediments to large mammal gene flow (Onorato et al., 2004; McRae et al., 2005), and likely are complicit in the isolation we detected between the border and east-central subpopulations. Addi- 


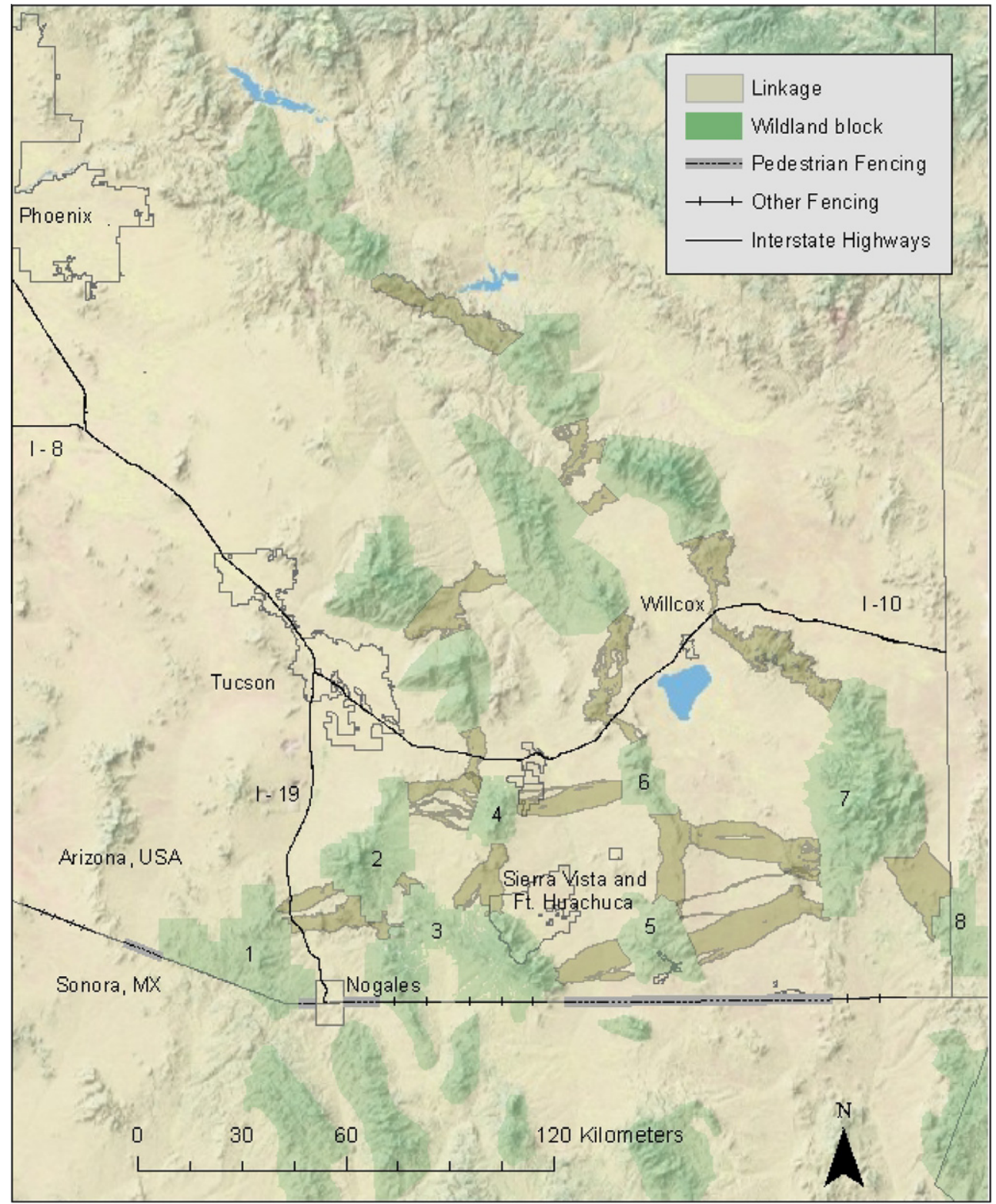

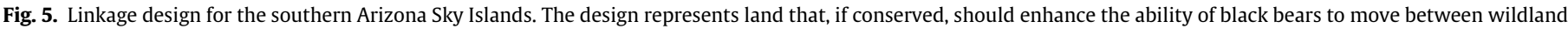
blocks.

tionally, it is feasible that Interstate Highways 10 and 19, the expanding human footprint near Tucson and other urban areas in southeastern Arizona, and the US-Mexico border fence represent contemporary impediments to movement and function to hasten genetic isolation of black bears in the border region. Indeed, there is a growing body of research indicating that urbanization and linear anthropogenic barriers can drive spatial structure in bear and other large carnivore populations (e.g., Kyle and Strobeck, 2001; Proctor et al., 2005; Burdett et al., 2010). Thus, while the desert basin has likely historically limited bear gene flow between the high desert and border regions, it is also likely that landscape fragmentation due to anthropogenic activities, including border security, has further limited gene flow.

Large carnivores are highly vagile, require a large amount of area to maintain a viable population and, as a result, are often highly vulnerable to habitat fragmentation (Weaver et al., 1996; Burdett et al., 2010) and loss of connectivity (Beckmann et al., 2010). Over the last few decades, central and southern Arizona has experienced rapid human population growth (Primack, 2006); urban expansion in the Tucson metropolitan area alone is expected to increase by $22 \%$ over the next decade (Pima Association of Governments: www.pagnet.org/regionaldata/population/ populationestimates/tabid/582/default.aspx). Our linkage design (Fig. 5) for Arizona's border Sky Islands provides a template for land-use managers and planners to prioritize conservation efforts where future development is most immediate and likely to adversely affect landscape connectivity. For example, we believe that conservation efforts aimed at protecting corridors within the Nogales-Sierra Vista-Tucson triangle should be prioritized. This area contains relatively high quality corridors linking wildland blocks (e.g., Tumacacori, Santa Rita, and Patagonia-Huachuca; Fig. 2) that either extend into Sonora, Mexico, or are immediately adjacent to Sonora wildland blocks (e.g., Sierra Cibuta, Sierra Pinito, and Sierra Chivato), thus providing the best opportunity for trans-border movement. Urbanization and additional stretches of the impermeable pedestrian fence along the international border have the po- 
tential to threaten connectivity in an area that may be critically important in facilitating trans-border dispersal, ultimately predisposing segments (i.e., the more isolated Sky Island mountain ranges) of the low density border black bear subpopulation to localized extinction.

Populations of black bears in the southwestern US and northern Mexico appear to display a metapopulation structure (Onorato et al., 2004), thus a significant step in ameliorating effects of habitat fragmentation will be to maintain or restore landscape connectivity within the system. The results of our analyses identified opportunities and challenges to maintaining connectivity among border Sky Islands and to the high desert region. A central challenge is that structural connectivity (based on length:width and\% suitable habitat metrics: Bennett et al., 1994) between border region wildland blocks varied considerably. Moreover, several adjacent wildland blocks that appear to benefit from sound structural connectivity also appear to be vulnerable to compromised functional connectivity due to increasing infrastructure. For example, the Tumacacori-Santa Rita corridor is bisected by Interstate Highway 19 (Fig. 5), which may degrade functional connectivity and reduce the likelihood of migrants from Sonora moving into the Sky Islands east of the interstate. Similarly, three other corridors (Whetstone-Rincon, Dragoon-Pinaleno, and Chiricahua-Pinaleno) potentially important in facilitating gene flow between the border and high desert regions, are bisected by Interstate Highway 10 (Fig. 5). These highway-corridor intersections would be ideal areas to target for road mitigation projects (e.g. road crossing structures designed specifically for black bears and other large mammals, see Beckmann et al., 2010) that enhance functional connectivity.

The US-Mexico borderland is one of the most biologically diverse and ecologically vulnerable regions in the United States (Cordova and de la Parra, 2007). Because rapid urbanization and border security activities threaten to alter the spatial structure of transborder wildlife populations (Flesch et al., 2010), it is important to identify opportunities to maintain or restore borderland connectivity. We identified suitable habitat and movement corridors for black bears in the Sky Island mountain ranges of southern Arizona, information that can help inform systems-level approaches to land-use planning and conservation (Moilanen et al., 2005). Currently, in the western US, there is opportunity to integrate connectivity conservation with land-planning (Western Governor's Association, 2008). For example, land-use planners in the Tucson metropolitan area have developed a regional conservation plan with a specific focus on maintaining wildlife linkages and increasing the permeability of transportation corridors (see Campbell and Kennedy, 2010). The information we present here, if incorporated into land-use planning, may aid in ameliorating the adverse effects of inevitable urbanization and border security activities. If connectivity can be maintained, there is greater likelihood of the longterm persistence of species such as black bears, mountain lions, and jaguars along the US-Mexico border.

\section{Acknowledgments}

J. Ng, R. Butler, T. Smith, and S. Boe provided assistance with data collection. S. Stone, B. Wakeling, L. Ordway, M. Disney, R. Thompson, M. Crabb, and J. Hanna helped coordinate collection of additional bear samples. We thank the Commandant of Fort Huachuca for providing access to the base. Funding was provided through the Federal Aid in Wildlife Restoration Act Project W-78-R of the Arizona Game and Fish Department's Research Branch, Arizona Game and Fish Department's Habitat Conservation Program and Wildlife Conservation Fund, Safari Club International, The Nature Conservancy-Northern Mexico Program, Summerlee Foundation, National Wildlife Research Center, and Wildlife Conservation Society.

\section{References}

Allison, P.D., 1999. Logistic Regression using the SAS System: Theory and Application. SAS Institute Inc., Cary, North Carolina, USA.

Baguette, M., Van Dyck, H., 2007. Landscape connectivity and animal behavior: functional grain as a key determinant for dispersal. Landscape Ecology 22, 1117-1129.

Bahre, C.J., Minnich, R.A., 2001. Madrean oak woodlands along the Arizona/Sonora boundary. Desert Plants 17, 3-14.

Beckmann, J.P., Clevenger, A.P., Huijser, M.P., Hilty, J.A., 2010. Safe Passages: Highways, Wildlife and Habitat Connectivity. Island Press, Washington, DC, USA.

Beier, P., Noss, R.F., 1998. Do habitat corridors provide connectivity? Conservation Biology 12, 1241-1252.

Bennett, A.F., Henein, K., Merriam, G., 1994. Corridor use and elements of corridor quality: chipmunks and fencerows in a farmland mosaic. Biological Conservation 68, 155-165.

Brody, A.J., Pelton, M.R., 1989. Effects of roads on black bear movements in western North Carolina. Wildlife Society Bulletin 17, 5-10.

Brown, D.E., 1994. Biotic Communities: Southwestern United States and Northwestern Mexico. University of Utah, Salt Lake City, UT, USA.

Brown, D.E., Lowe, C.H., 1974. A digitized computer-compatible classification for natural and potential vegetation in the Southwest with particular reference to Arizona. Journal of Arizona Academy of Science 9, 3-11.

Burdett, C.L., Crooks, K.R., Theobald, D.M., Wilson, K.R., Boydston, E.E., Lyren, L.M., Fisher, R.N., Vickers, T.W., Morrison, S.A., Boyce, W.M., 2010. Interfacing models of wildlife habitat and human development to predict the future distribution of puma habitat. Ecosphere 1, 1-21.

Campbell, C., Kennedy, K., 2010. The Sonoran Desert Conservation Plan and Regional Transportation Authority: citizen support for habitat connectivity and highway mitigation. In: Beckmann, J.P., Clevenger, A.P., Huijser, M.P., Hilty, J.A. (Eds.), Safe Passages: Highways, Wildlife and Habitat Connectivity. Island Press, Washington, DC, USA, pp. 277-308.

Cordova, A., de la Parra, C.A., 2007. A Barrier to Our Shared Environment: the Border fence Between the United States and Mexico. National Institute of Ecology, Mexico City, MX.

Cunningham, S.C., Ballard, W.B., 2004. Effects of wildfire on black bear demographics in central Arizona. Wildlife Society Bulletin 32, 928-937.

Cunningham, S.C., Ballard, W.B., Monroe, L.M., Rabe, M.J., Bristow, K.D., 2003. Black bear habitat use in burned and unburned areas, central Arizona. Wildlife Society Bulletin 31, 86-792.

Doan-Crider, D.L. 1995. Population Characteristics and Home Range Dynamics of a Black Bear Population in Northern Coahuila, Mexico. Thesis, Texas A \& M University, Kingsville.

Doan-Crider, D.L., Hellgren, E.C., 1996. Population characteristics and winter ecology of black bears in Coahuila, Mexico. Journal of Wildlife Management 60, 398-407.

Ennis, S., Gallagher, T.F., 1994. A PCR-based sex-determination assay in cattle based on the bovine amelogenin locus. Animal Genetics 25, 425-427.

Evanno, G., Regnaut, S., Goudet, J., 2005. Detecting the number of clusters of individuals using the software STRUCTURE: a simulation study. Molecular Ecology 14, 2611-2620.

Flesch, A.D., Epps, C.W., Cain, J.W., Clark, M., Krausman, P.R., Morgart, J.R., 2010. Potential effects of the United States-Mexico border fence on wildlife. Conservation Biology 24, 171-181.

Guillot, G., Estoup, A., Mortier, F., Cosson, J-F., 2005a. A spatial statistical model for landscape genetics. Genetics 170, 1261-1280.

Guillot, G., Mortier, F., Estoup, A., 2005b. Geneland: A computer package for landscape genetics. Molecular Ecology Notes 5, 708-711.

Hanski, I., 1999. Habitat connectivity, habitat continuity, and metapopulations in dynamic landscapes. Oikos 87, 209-219.

Hardy, O.J., Vekemans, X., 2002. SPAGeDi: a versatile computer program to analyse spatial genetic structure at the individual or population levels. Molecular Ecology Notes 2, 618-620.

Hayward, M.W., Kerley, G.I.H., 2009. Fencing for conservation: restriction of evolutionary potential or a riposte to threatening processes? Biological Conservation 142, 1-13.

Johnson, A.R., Wiens, J.A., Milne, B.T., Crist, T.O., 1992. Animal movements and population-dynamics in heterogeneous landscapes. Landscape Ecology 7, 63-75.

Kohn, M., Wayne, R.K., 1997. Facts from feces revisited. Trends in Ecology and Evolution 12, 223-227.

Kyle, C.J., Strobeck, C., 2001. Genetic structure of North American wolverine (Gulo gulo) populations. Molecular Ecology 10, 337-347.

Lande, R., 1988. Genetics and demography in biological conservation. Science 241, 1455-1460.

LeCount, A.L., 1982. Population characteristics of Arizona black bears. Journal of Wildlife Management 46, 861-868.

Lewis, P.O., Zaykin, D., 1999. Genetic Data Analysis: Computer Program for the Analysis of Allelic Data, Version 1.1. Free Program Distributed by the Authors Over the Internet from the GDA Homepage. <http://chee.unm.edu>.

Lima, S.L., Zollner, P.A., 1996. Towards a behavioral ecology of ecological landscapes. Trends in Evolution and Ecology 11, 131-135.

Majka, D., Jenness, J., Beier, P. 2007. CorridorDesigner: ArcGIS tools for Designing and Evaluating Corridors. <http://corridordesign.org>. 
McRae, B.H., Beier, P., Dewald, L.E., Huynh, L.Y., Kiem, P., 2005. Habitat barriers limit gene flow and illuminate historical events in a wide-ranging carnivore, the American puma. Molecular Ecology 14, 1965-1977.

Miller, C.R., Joyce, P., Waits, L.P., 2005. A new method for estimating the size of small populations from genetic mark-recapture data. Molecular Ecology 14, 1991-2005.

Moilanen, A., Franco, A.M.A., Eary, R.I., Fox, R., Wintle, B., Thomas, C.D., 2005. Prioritizing multiple-use landscapes for conservation: methods for large multispecies planning problems. Proceedings of the Royal Society of London, Series B 272, 1885-1891.

Onorato, D.P., Hellgren, E.C., Van Den Bussche, R.A., Doan-Crider, D.L., 2004. Phylogeographic patterns within a metapopulation of black bears (Ursus americanus) in the American Southwest. Journal of Mammalogy 85, 140-147.

Paetkau, D., Calvert, W., Stirling, I., Strobeck, C., 1995. Microsatellite analysis of population structure in Canadian polar bears. Molecular Ecology 4, 347-354.

Paetkau, D., Shields, G.F., Strobeck, C., 1998. Gene flow between insular, coastal and interior populations of brown bears in Alaska. Molecular Ecology 7, 1283-1292.

Pelton, M.R., Coley, A.B., Eason, T.H., Doan Martinez, D.L., Pederson, J.A., van Manen, F.T., Weaver, K.M. 1998. American Black Bear Conservation Action Plan. In: Servheen, C., Herrero, S., Peyton, B. (Eds.), Bears: Status Survey and Conservation Action Plan, IUCN/SSC Bear and Polar Bear Specialist Groups, IUCN, Gland, Switzerland and Cambridge, UK, pp. 144-156.

Primack, R.B., 2006. Habitat destruction. In: Primack, R.B. (Ed.), Essentials of Conservation Biology. Sinauer Associates, Sunderland, UK, pp. 189-193.

Pritchard, J.K., Stephens, M., Donnelly, P., 2000. Inference of population structure using multilocus genotype data. Genetics 155, 945-959.

Proctor, M.F., McLellan, B.N., Strobeck, C., Barclay, R.M.R., 2005. Genetic analysis reveals demographic fragmentation of grizzly bears yielding vulnerably small populations. Proceedings of the Royal Society of London, Series B 272, 24092416.

Raymond, M., Rousset, F., 2000. GENEPOP Version 3.4. <http://wbiomed.curtin. edu.au/genepop>.

Sierra-Corona, R., Sayago-Vazquez, I.A., Silva-Hurtado, M.C., Lopez-Gonzalez, C.A 2005. Black bear abundance, habitat use, and food habits in the Sierra San Luis, Sonora, Mexico. In: USDA Forest Service Proceedings RMRS-P-36.
Taberlet, P., Griffin, S., Goossens, B., Questiau, S., Manceau, V., Escaravage, N., Waits, L.P., Bouvet, J., 1996. Reliable genotyping of samples with very low DNA quantities using PCR. Nucleic Acids Research 24, 3189-3194.

Taberlet, P., Waits, L.P., Luikart, G., 1999. Noninvasive genetic sampling: look before you leap. Trends in Ecology and Evolution 14, 323-327.

Tallmon, D.A., Luikart, G., Waples, R.S., 2004. The alluring simplicity and complex reality of genetic rescue. Trends in Ecology and Evolution 19, 489-496.

United States Customs and Border Protection, 2009. Fence Specifications. <http:// www.cbp.gov/xp/cgov/border_security/ti/ti_mr/ctimr/about_ctimr/ ctimr_work/fence/fence_specs/>.

Valiere, N., 2002. GIMLET: A computer program for analyzing genetic individua identification data. Molecular Ecology Notes 2, 377-379.

Vasquez-Leon, M., Liverman, D., 2004. The political ecology of land-use change: affluent ranchers and destitute farmers in the Mexican Municipio of Alamos. Human Organization 63, 21-33.

Vos, C.C., Verboom, J., Opdam, P.F.M., Ter Braak, C.J.F., 2001. Toward ecologically scaled landscape indices. The American Naturalist 183, 24-41.

Vos, C.C., Antonisse-DeJong, A.G., Goedhart, P.W., Smulders, M.J.M., 2001. Genetic dissimilarity as a measure for connectivity between fragmented populations of the moor frog (Rana arvalis). Heredity 86, 598-608.

Wallmo, O.C., 1955. Vegetation of the Huachuca Mountains, Arizona. American Midland Naturalist 54, 466-480.

Weaver, J.L., Paquet, P.C., Ruggiero, L.F., 1996. Resilience and conservation of large carnivores. Conservation Biology 10, 964-976.

Western Governors' Association, 2008. Wildlife Corridors Initiative: June 2008 Report. Western Governor's Association, Jackson, Wyoming, USA.

With, K.A., Gardner, R.H., Turner, M.G., 1997. Landscape connectivity and population distributions in heterogeneous environments. Oikos 78, 151-169.

Woodroffe, R., Ginsberg, J.R., 1998. Edge effects and the extinction of populations inside protected areas. Science 280, 2126-2128.

Woods, J.G., Paetkau, D., Lewis, D., McLellan, B.N., Proctor, M., Strobeck, C., 1999 Genetic tagging of free-ranging black and brown bears. Wildlife Society Bulletin 27, 616-627. 